\title{
EFFECTS OF DISCRETE NUCLEAR U.V.-MICROBEAM IRRADIATION ON HERPES VIRUS AND SV40 INFECTION
}

\author{
I. I. DEAK* AND V. DEFENDI $\dagger$ \\ Sir William Dunn School of Pathology, University of Oxford, Oxford, England
}

\begin{abstract}
SUM MARY
The requirement for a nucleolus in the expression of structural genes of nuclear viruses was examined by means of experiments in which the nucleolus or other parts of the nucleus were inactivated by a microbeam of ultraviolet light. These experiments showed that the expression of such genes is not dependent on nucleolar function. This conclusion is discussed in the light of previous experiments in which similar inactivation of the nucleolus was shown to prevent the expression of cellular structural genes.
\end{abstract}

\section{INTRODUCTION}

Recent studies have indicated that in animal cells some function located at or near the nucleolus is essential for the full expression of structural genes (Harris, Sidebottom, Grace \& Bramwell, I 969; Deák, Sidebottom \& Harris, I 972). When a nucleus contains a solitary nucleolus and this nucleolus is inactivated by a microbeam of ultraviolet light, structural genes fail to be expressed (Deák et al. 1972). It has been suggested that the nucleolus might exercise this control by governing the flow to the cytoplasm not only of the RNA made at the nucleolar site but also of RNA made elsewhere in the nucleus and, in particular, the RNA that carries the specifications for the synthesis of proteins. This view receives some support from experiments in which it has been shown that inactivation of the nucleolus, where there is only one in the nucleus, reduces the flow of labelled RNA from nucleus to cytoplasm to trace levels (Sidebottom \& Harris, 1969; Deák, 1973). It was of interest to see whether the expression of viral genes in viruses that develop in the cell nucleus is also subject to nucleolar control. Like messenger RNA (mRNA) of cellular origin, the mRNA of viruses that replicate in the nucleus passes to the cytoplasm to be translated (Wall, Philipson \& Darnell, I972). The effects of nucleolar irradiation on the expression of viral genes can therefore be compared with the results of previous experiments in which the expression of cellular structural genes was studied under similar conditions. The two viruses examined in the present paper were herpes virus and simian virus $4^{\circ}$ $\left(\mathrm{SV}_{4} \mathrm{O}\right)$.

- Present address: California Institute of Technology, Pasadena, California 91125, U.S.A.

$\dagger$ This work was conducted while a guest at the Imperial Cancer Fund, Lincoln's Inn Field, London, on sabbatical leave from the Wistar Institute, Philadelphia, Pa., U.S.A. 


\section{METHODS}

Virus. Herpes virus type I was supplied by Dr J. F. Watkins. Stocks were grown in BSC-I cells. $\mathrm{SV}_{40}$ virus (strain $\mathrm{RH}_{9 \mathrm{I}} \mathrm{I}$ ) was grown in $\mathrm{CV}-\mathrm{I}$ cells after infection at a multiplicity of o.or plaque-forming units (p.f.u.) per cell.

\section{Cells}

BSC-I cells, a line derived from Cercopithecus aethiops kidney cells (Hopps, Bernheim, Nisalak, Tjio \& Smadel, I 963 ), were used for all experiments. They were maintained in Eagle's Minimal Essential Medium (Eagle, 1959) containing 10\%, foetal calf serum (Flow Laboratories, Irvine, Scotland).

\section{Ultraviolet microbeam}

The apparatus was constructed by Dr E. Sidebottom and was used, with minor modifications, as described by Sidebottom \& Harris (1969). A suitable dose of ultraviolet light was determined empirically by varying the time of irradiation. The dose used was enough to reduce the incorporation of tritiated uridine into the irradiated area by more than $95 \%$. Nucleoli and other parts of the nucleus of BSC-I cells were irradiated by a beam $4 \mu \mathrm{m}$ in diameter for $7 \mathrm{~s}$; whole nuclei, by a beam $25 \mu \mathrm{m}$ in diameter for the same time. Nucleoli and other nuclear areas in erythrocyte nuclei reactivated in heterokaryons were irradiated by a beam $1.5 \mu \mathrm{m}$ in diameter for $10 \mathrm{~s}$; whole erythrocyte nuclei in heterokaryons were irradiated by a beam $7 \mu \mathrm{m}$ in diameter for the same time.

\section{Localization of cells}

A chromium grid was shadowed on to the quartz coverslips used in the microbeam irradiation experiments. The positions of the cells relative to the chromium grid were recorded before they were irradiated so that cells could be found again.

\section{Virus infection}

One hour after irradiation with the microbeam the cells were exposed to herpes virus at a multiplicity of infection (m.o.i.) of 20 p.f.u. per cell or to $\mathrm{SV}_{4} 0$ virus at an m.o.i. of ro p.f.u. per cell for $\mathrm{I} h$ at $37^{\circ} \mathrm{C}$. The medium was then replaced.

\section{Autoradiography}

Autoradiography was done by the technique of Messier \& Leblond (1957). Coverslips were mounted on slides with DePex (G. T. Gurr, London). Acid-soluble precursors were extracted with $5 \%$ trichloroacetic acid at $4{ }^{\circ} \mathrm{C}$ for $30 \mathrm{~min}$ and the slides then washed. Slides were dipped into $\mathrm{K}_{5}$ liquid emulsion (Ilford Ltd, Ilford, Essex) diluted $2: \mathrm{I}(\mathrm{v} / \mathrm{v})$ with distilled water, and then left to dry at room temperature for $2 \mathrm{~h}$. Autoradiographs were exposed for 4-8 days and then developed with Kodak D $19 \mathrm{~B}$ developer (Kodak Ltd, Hemel Hempstead, Herts) and fixed with Fix-Sol (Johnsons, Hendon, London) diluted $1: 3$ with distilled water. The developed autoradiographs were then stained for 5-10 min in $10 \%$ Giemsa stain (G. T. Gurr) in distilled water buffered to $\mathrm{pH} 6 \cdot 8$.

\section{Viral markers}

\section{(1) Herpes virus}

Viral antigen. Antisera against herpes viral antigens were supplied by Professor P. Wildy and $\mathrm{Dr}$ R. Madeley. The sera were prepared in rabbits by repeated injections of virus-infected rabbit kidney cells. The presence of viral antigens was detected by radioimmunoassay (Hunter, r 973). Coverslips bearing infected cells were fixed $20 \mathrm{~h}$ after infection with ethanol:acetone $\left(\mathrm{I}: \mathrm{I} \mathrm{v} / \mathrm{v}\right.$ ) at $-20^{\circ} \mathrm{C}$. The cells were then treated with the rabbit antivirus antiserum at a dilu- 
tion of 1 in $10^{3}$ for $30 \mathrm{~min}$ at room temperature. The coverslips were then washed, and exposed to ${ }^{125}$ I-labelled (sp. act. $75 \mu \mathrm{Ci} / \mu \mathrm{g}$ protein) horse antirabbit immunoglobulin (prepared by Dr A. Williams) for $30 \mathrm{~min}$ at room temperature. The coverslips were then washed and autoradiographs prepared.

Synthesis of viral $D N A$. Nine hours after infection by the virus the cells were exposed for $\mathrm{I} h$ to tritiated thymidine (Radiochemicals Ltd, Amersham, Bucks., sp. act. $23 \mathrm{Ci} / \mathrm{mm}$ ) at a concentration of $10 \mu \mathrm{Ci} / \mathrm{ml}$. The cells were then fixed with methanol for $1 \mathrm{~min}$ and autoradiographs prepared.

Haemadsorption mediated by concanavalin $A$. The binding of concanavalin $\mathrm{A}$ to cells can be detected by haemadsorption (Furmanski, Phillips \& Lubin, 1972). The agglutinability of cells by concanavalin $A$ increases markedly after infection with herpes virus (Poste, 1972); haemadsorption mediated by concanavalin $A$ increases likewise. It is not known whether the changes in the cell surface underlying these effects are due to the synthesis of new proteins coded by the virus.

Coverslips were treated with concanavalin A (Miles-Yeda Ltd, Illinois, U.S.A.) at a concentration of $500 \mu \mathrm{g} / \mathrm{ml}$ for $30 \mathrm{~min}$ at $37^{\circ} \mathrm{C}$. They were then washed and covered with a $2 \%$ $(v / v)$ suspension of washed sheep red cells (Burroughs Wellcome Ltd, Kent, England) in Minimal Essential Medium for $30 \mathrm{~min}$ at $37^{\circ} \mathrm{C}$. Unattached red cells were then washed off and the cultures fixed in methanol and stained.

\section{(2) $\mathrm{SV}_{40}$ virus}

Viral $T$ and $V$ antigens. Cells on coverslips were fixed in $\mathrm{I}: \mathrm{I}$ ethanol:acetone at $-20{ }^{\circ} \mathrm{C}$ $48 \mathrm{~h}$ after infection (for $\mathrm{T}$ antigen) or $72 \mathrm{~h}$ after infection (for $\mathrm{V}$ antigen). $\mathrm{T}$ and $\mathrm{V}$ antigens were assayed by indirect immunofluorescence (Gilden, Carp, Taguchi $\&$ Defendi, 1965).

Virus-induced synthesis of DNA. The cells were exposed for $\mathrm{I} h$ to ${ }^{3} \mathrm{H}-\mathrm{TdR}(\mathrm{r} \circ \mu \mathrm{Ci} / \mathrm{ml}) 4^{8} \mathrm{~h}$ after infection; the coverslips were then fixed in methanol and prepared for autoradiography.

$\mathrm{SV}_{40}$ does not induce host DNA synthesis in BSC-I cells (Ritzi \& Levine, I970); the incorporation of tritiated thymidine into infected cells later in infection is taken as a measure of viral DNA synthesis.

\section{Cell fusion}

BSC-I cells were given a dose of $100 \mathrm{~J} \mathrm{~kg}^{-1}$ of gamma-radiation from a cobalt-60 source and then fused with red blood cells from I I-day-old chick embryos, as described by Harris, Watkins, Ford \& Schoefl (1966). The fused cells were plated at a suitable density on to shadowed quartz coverslips.

\section{RESULTS}

Four groups of cells were compared: (I) Cells in which the whole nucleus was irradiated with the ultraviolet microbeam. (2) Cells with nuclei containing a solitary nucleolus which was irradiated. (3) Cells with nuclei containing two nucleoli one of which was irradiated. (4) Cells in which an area of nucleoplasm was irradiated. These groups of cells were infected with the virus immediately after irradiation with the microbeam. Two additional groups served as controls: virus-infected cells that were not irradiated with the microbeam and cells that were neither infected nor irradiated.

\section{Herpes virus}

The effects of irradiation of different parts of the cell nucleus on the appearance of viral markers is shown in Table $\mathrm{I}$. The results show that irradiation of the whole nucleus virtually prevents the appearance of viral antigens, of incorporation of tritiated thymidine, and of changes in the cell surface demonstrated by concanavalin Amediated haemadsorption. Irradiation of any site within the nucleus causes some 
reduction in the proportion of cells containing viral antigens but not in the proportion of those expressing other markers of viral infection. There is no significant difference between cells in which a single nucleolus was irradiated, and those in which one

Table I. Effect of u.v. irradiation on herpes virus infection of $B S C-\mathrm{I}$ cells

\begin{tabular}{|c|c|c|c|c|c|}
\hline \multirow[b]{2}{*}{ Marker } & \multicolumn{5}{|c|}{ Infected cells } \\
\hline & Unirradiated & $\begin{array}{l}\text { Nucleus } \\
\text { irradiated }\end{array}$ & $\begin{array}{l}\text { Single } \\
\text { nucleolus } \\
\text { irradiated }\end{array}$ & $\begin{array}{l}\text { One } \\
\text { nucleolus } \\
\text { of two } \\
\text { irradiated }\end{array}$ & $\begin{array}{l}\text { Nucleo- } \\
\text { plasmic } \\
\quad \text { area } \\
\text { irradiated }\end{array}$ \\
\hline $\begin{array}{l}\text { Viral } \\
\text { antigen }\end{array}$ & $136 / 179(76)$ & $6 / 187(3)$ & $61 / 160(38)$ & $63 / 128(49)$ & $93 / 228(41)$ \\
\hline $\begin{array}{l}\text { Tritiated } 74 / 264(28) \\
\text { thymidine } \\
\text { incorporation } \dagger\end{array}$ & $121 / 195(65)$ & $4 / 140(3)$ & $108 / 161(67)$ & I $21 / 175(69)$ & $97 / 127(76)$ \\
\hline $\begin{array}{l}\text { Concanava- } 13 / 73 \text { (18) } \\
\text { lin A bindingt }\end{array}$ & $44 / 69(64)$ & $13 / 50(26)$ & $52 / 104(50)$ & $46 / 71(65)$ & $45 / 7 \circ(65)$ \\
\hline \multicolumn{6}{|c|}{$\begin{array}{l}\text { Number of positive cells out of the total number examined; in parentheses, percentage of } \\
\text { positive cells. } \\
\dagger \text { A cell was scored as positive if the autoradiograph showed more than ro grains per nucleus. } \\
\ddagger \text { A cell was scored as positive if } 10 \text { or more erythrocytes were attached to it. }\end{array}$} \\
\hline
\end{tabular}

Table 2. Effect of u.v. irradiation on $S_{4}$ o infection of BSC-I cells

\begin{tabular}{|c|c|c|c|c|c|c|}
\hline \multirow[b]{2}{*}{ Marker } & \multirow[b]{2}{*}{$\begin{array}{l}\text { Uninfected } \\
\text { cells }\end{array}$} & \multicolumn{5}{|c|}{ Infected cells } \\
\hline & & Unirradiated & $\begin{array}{l}\text { Nucleus } \\
\text { irradiated }\end{array}$ & $\begin{array}{c}\text { Single } \\
\text { nucleolus } \\
\text { irradiated }\end{array}$ & $\begin{array}{c}\text { One } \\
\text { nucleolus } \\
\text { of two } \\
\text { irradiated }\end{array}$ & $\begin{array}{l}\text { Nucleo- } \\
\text { plasmic } \\
\text { area } \\
\text { irradiated }\end{array}$ \\
\hline $\begin{array}{l}\mathrm{T} \text { antigen } \\
\mathrm{V} \text { antigen } \\
\text { Tritiated } \\
\text { thymidine } \\
\text { incorporatic }\end{array}$ & $\begin{array}{c}0 / 200(0) \\
0 / 100(0) \\
74 / 264 t(28)\end{array}$ & $\begin{array}{l}53 / 65(81) \\
84 / 96(88) \\
70 / 105(67)\end{array}$ & $\begin{array}{c}2 / 64(3) \\
10 / 92(\mathrm{II}) \\
\mathrm{I} / \mathrm{I} 8(6)\end{array}$ & $\begin{array}{l}21 / 33(64) \\
50 / 61(82) \\
22 / 34(65)\end{array}$ & $\begin{array}{l}32 / 39(82) \\
17 / 19(90) \\
22 / 30(73)\end{array}$ & $\begin{array}{l}45 / 66(68) \\
45 / 55(82) \\
26 / 42(62)\end{array}$ \\
\hline \multicolumn{7}{|c|}{$\begin{array}{l}\text { Number of positive cells out of total number examined; in parentheses, percentage of posi- } \\
\text { tive cells. } \\
+ \text { A cell was scored as positive if the autoradiograph showed more than io grains per nucleus. }\end{array}$} \\
\hline
\end{tabular}

nucleolus of two within the same nucleus was irradiated or those in which a nucleoplasmic area was irradiated. These results indicate that the expression of herpes virus markers does not require nucleolar activity.

\section{Simian virus 40}

The results of similar experiments with $\mathrm{SV}_{4}$ o are shown in Table 2. It is again clear that irradiation of the whole nucleus produces complete inhibition of synthesis 
of $\mathrm{T}$ and $\mathrm{V}$ antigens and of incorporation of ${ }^{3} \mathrm{H}-\mathrm{TdR}$. Irradiation of limited regions of the nucleus, including irradiation of a solitary nucleolus within a nucleus, has no effect on the expression of $\mathrm{SV}_{4}$ o viral markers.

\section{Expression of $S V 40$ markers in heterokaryons}

The results described above indicate that for both of these intranuclear viruses the expression of viral genes or of viral-induced functions in BSC-I cells does not require nucleolar activity. This conclusion is clearly at variance with the results of previous experiments in which it was shown that the expression of structural genes in reactivated chick erythrocyte nuclei requires some nucleolar function (Deák et al. 1972). A possible explanation of these contrasting findings might be that the organization of the nucleolus in BSC-I cells differs from that in reactivating erythrocyte nuclei. It was therefore desirable to determine whether virus develops within the reactivated erythrocyte nucleus, and, if so, whether nucleolar function is required for the expression of viral genes.

Table 3. Expression of $S V_{40}$ markers in heterokaryons*

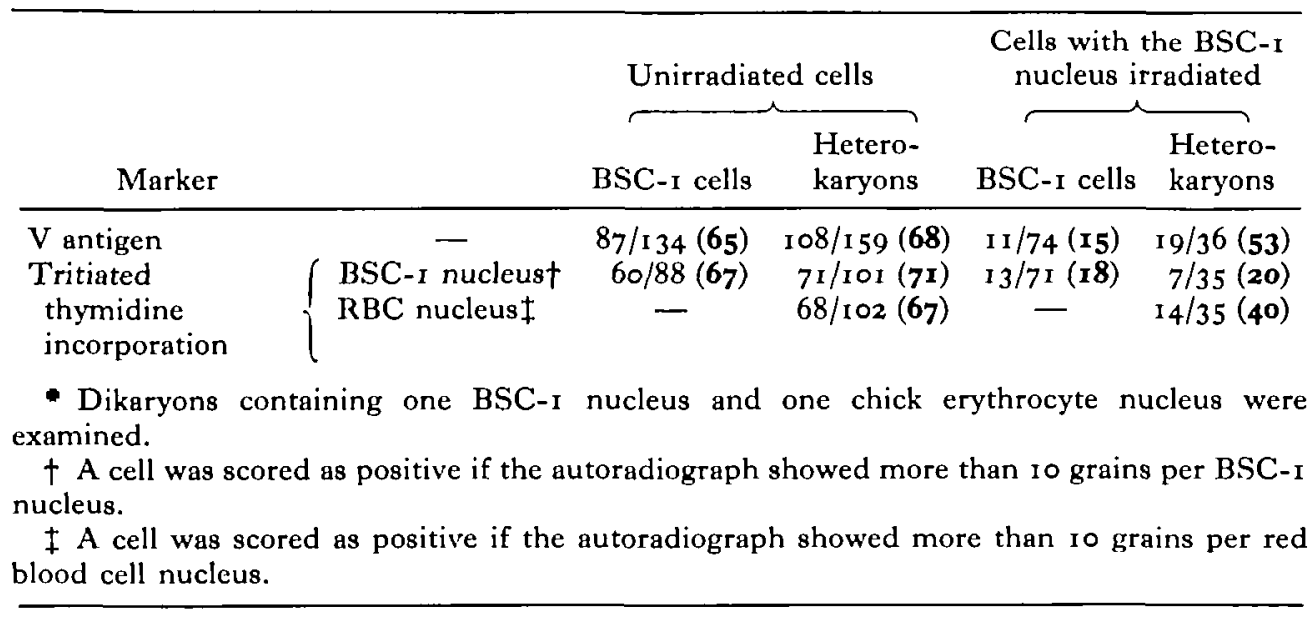

Heterokaryons were made by introducing embryonic chick erythrocyte nuclei into BSC-I cells. The expression of $\mathrm{SV}_{4}$ o viral markers in those heterokaryons in which the red blood cell nucleus contained at least one reactivating nucleolus was examined after various nuclear components had been inactivated by the ultraviolet microbeam.

As a control, unirradiated heterokaryons were infected with $\mathrm{SV}_{4} \mathrm{O}$ and then scored for $\mathrm{V}$ antigen and for ${ }^{3} \mathrm{H}-\mathrm{TdR}$ incorporation. Both the BSC-I and the red blood cell nuclei were found to be positive for these markers of viral expression. When the nuclei of mononucleate BSC-I cells were irradiated, the proportion of cells synthesizing $\mathrm{V}$ antigen was greatly reduced (Table 2). When, however, heterokaryons in which the BSC-I nuclei had been irradiated were examined, it was found that the proportion of cells synthesizing $\mathrm{V}$ antigen did not fall markedly (Table 3 ). In such cells $\mathrm{V}$ antigen appeared in both the BSC-I and the erythrocyte nuclei. These results 
suggest that infecting $\mathrm{SV}_{4} \mathrm{ODNA}$ can enter the erythrocyte nuclei and direct the synthesis of $\mathrm{V}$ antigen in the cytoplasm of the heterokaryons. The $\mathrm{V}$ antigen then passes from the cytoplasm into both of the nuclei in the cell (Steplewski \& Koprowski, 1969). This hypothesis is supported by the results of ${ }^{3} \mathrm{H}-\mathrm{TdR}$ incorporation (Table 3 ) which shows that in heterokaryons in which the BSC-I nuclei have been irradiated the erythrocyte nuclei are capable of incorporating tritiated thymidine, probably into viral DNA.

Table 4 shows the effects on the expression of $\mathrm{SV}_{4} 0$ markers of irradiation of parts of the erythrocyte nuclei in heterokaryons in which the BSC-I nuclei had already been inactivated. Irradiation of entire erythrocyte nuclei in such heterokaryons results in a marked reduction in the capacity of the cells to synthesize $\mathrm{V}$ antigen and to incorporate ${ }^{3} \mathrm{H}-\mathrm{TdR}$. If, however, parts of the erythrocyte nuclei in such heterokaryons are irradiated, the viral markers continue to be expressed irrespective of the site of irradiation within the erythrocyte nucleus: irradiation of the erythrocyte nucleolus has no more effect than irradiation of a nucleoplasmic area or of one nucleolus of two within the same nucleus. These results show that although the erythrocyte nucleus requires a functional nucleolus to express its own structural genes, viral genes presumably present in the erythrocyte nucleus can be expressed even if the nucleolus has been inactivated.

\section{DISCUSSION}

Previous work has indicated that the expression of cellular genes is dependent on some activity associated with the nucleolus (Deák et al. 1972); it has been suggested that the nucleolus governs the flow of informational RNA from the DNA on which it is synthesized to the cytoplasm (Harris et al. 1969).

The results presented here show that expression of the genes of nuclear viruses, unlike that of cellular genes, is not dependent on the nucleolus. This seems to be the case even though there is considerable evidence, at least in the case of $\mathrm{SV}_{4} \mathrm{O}$, that the viral DNA is integrated into the cell DNA during primary infection of permissive cells (Hirai \& Defendi, 1972; Hölzel \& Sokol, 1974) and that a large mRNA that contains sequences complementary to both viral and cellular DNA is synthesized during infection (Jaenisch, 1972; Rozenblatt \& Winocour, 1972). Two explanations of this independence may be considered. Viral infection may result in changes in the nuclear membrane that lead to an increased permeability to RNA. Thus in uninfected cells the release of messenger RNA into the cytoplasm may be controlled by a nucleolar-associated mechanism, whereas in virus-infected cells the mRNA may be able to leak through the nuclear membrane and therefore be available for use in the cytoplasm without the mediation of the nucleolus. It is also possible that cellular messenger RNA must be processed in the nucleus by a nucleolus-associated mechanism, but that viral messengers do not have to be processed in this way or can replace part of the processing mechanism so as to bypass the requirement for a nucleolus.

The data presented in this paper also strongly suggest that $\mathrm{SV}_{40}$ DNA can enter 
reactivated chick erythrocyte nuclei in heterokaryons and direct the synthesis both of viral antigen and of DNA. The erythrocyte nuclei have therefore presumably been rendered permissive to $\mathrm{SV}_{40}$ infection by the BSC-I cytoplasm.

This work was done while I.I.D. held a Grocers' Company Research Fellowship at New College, Oxford. We thank Professor Henry Harris for advice and Mrs J. P. McAvoy for technical assistance.

\section{REFERENCES}

DEAK, I. I. (1973). Further experiments on the role of the nucleolus in the transfer of RNA from nucleus to cytoplasm. F. Cell Sci. 13, 395-401.

Dék, I., Sidebottom, E. \& Harris, H. (1972). Further experiments on the role of the nucleolus in the expression of structural genes. F. Cell Sci. II, 379-39r.

EAGLE, H. (1959). Amino acid metabolism in mammalian cell cultures. Science, N.I. I30, 432-437.

Furmanski, P., Phillips, P. G. \& Lubin, M. (1972). Cell surface interactions with concanavalin A: determination by microhaemadsorption. Proc. Soc. exp. Biol. Med. 140, 2 I6-2 19.

Gilden, R. V., CARP, R. I., TAGUChI, F. \& DeFENDI, V. (1965). The nature and localization of the $\mathrm{SV}_{40} \mathrm{O}-\mathrm{induced}$ complement-fixing antigen. Proc. natn. Acad. Sci. U.S.A. 53, 684-692.

Harris, H., Sidebottom, E., Grace, D. M. \& Bramwell, M. E. (i969). The expression of genetic information: a study with hybrid animal cells. F. Cell Sci. 4, 499-525.

Harris, H., Watkins, J. F., Ford, C. E. \& Schoefl, G. I. (ig66). Artificial heterokaryons of animal cells from different species. 7 . Cell Sci. I, I-30.

Hirai, K. \& DeFENDI, V. (1972). Integration of simian virus 40 DNA into the DNA of permissive monkey cells. F. Virol. 9, 705-707.

Hölzel, F. \& SoKoL, F. (1974). Integration of progeny simian virus 40 DNA into the host cell genome. J. molec. Biol. 84, 423-444.

Hopps, H. E., Bernheim, B. C., Nisalak, A., Tjio, J. H. \& Smadel, J. E. (ig63). Biologic characteristics of a continuous kidney cell line derived from the African green monkey. f. Immun. 9I, 4I6-424.

Hunter, W. M. (I973). Radioimmunoassay. In Handbook of Experimental Imnunology, 2nd edn. vol. I (ed. D. M. Weir), chapter i 7, pp. I-36. Oxford: Blackwell.

JAENISCH, R. (1972). Evidence for $\mathrm{SV}_{40}$ specific RNA containing virus and host specific sequences. Nature, Nero Biol. 235, 46-47.

Messier, B. \& LeBlond, C. P. (1957). Preparation of coated radioautographs by dipping sections in fluid emulsion. Proc. Soc. exp. Biol. Med. 96, 7-10.

Poste, G. (1972). Changes in susceptibility of normal cells to agglutination by plant lectins following modification of cell coat material. Expl Cell Res. 73, 319-328.

Ritzi, E. \& Levine, A. J. (i970). Deoxyribonucleic acid replication in simian virus 40-infected cells. III. Comparison of simian virus 40 lytic infection in three different monkey kidney cell lines. F. Virol. 5, 686-692.

RozenblatT, S. \& Winocour, E. (1972). Covalently linked cell and SV40-specific sequences in an RNA from productively infected cells. Virology 50, 558-566.

SidebotTom, E. \& Harris, H. (1969). The role of the nucleolus in the transfer of RNA from nucleus to cytoplasm. F. Cell Sci. 5, 35 I-364.

StePlewski, Z. \& Koprowski, H. (I969). Development of SV40 coat protein antigen in nonpermissive nuclei in heterokaryocytes. Expl Cell Res. 57, 433-440.

Wall, R., Philipson, L. \& Darnell, J. E. (1972). Processing of adenovirus specific nuclear RNA during virus replication. Virology 50, 27-34.

(Received 5 October 1974) 